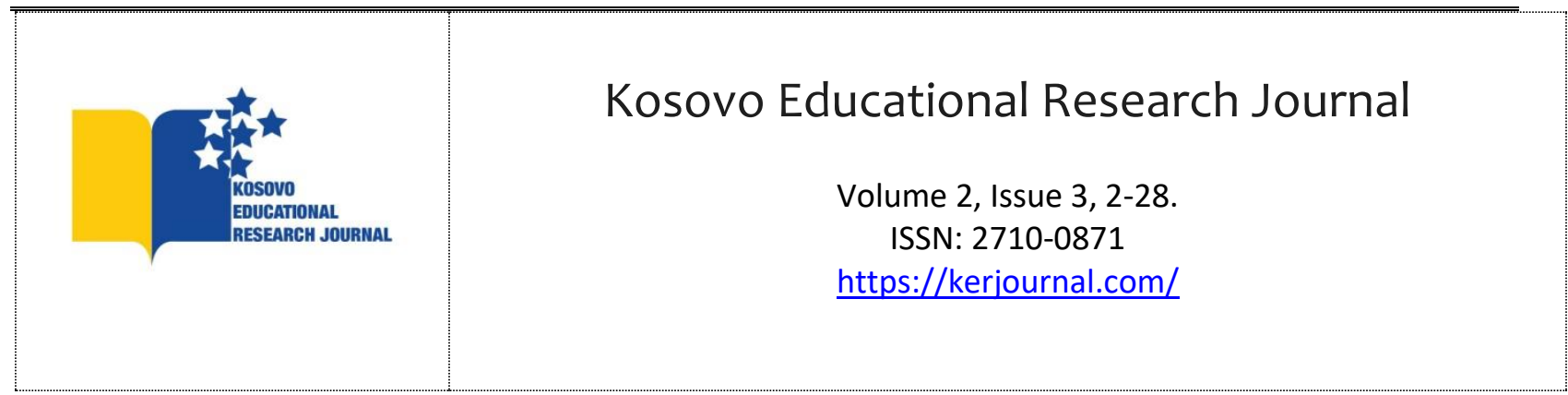

\title{
Eğitim Fakültesi Öğrencilerinin Türk Eğitim Sistemi'nde İmkân ve Fırsat Eşitliğinin Gerçekleşmesine Yönelik Görüşleri ${ }^{1}$
}

\author{
Cem TUNA* \\ Recep Tayyip Erdoğan Üniversitesi, TÜRKIYE
}

Özet: Bu çalışmada eğitim fakültesi öğrencilerin görüşlerine göre Türk eğitim sisteminde imkân ve fırsat eşitliğinin gerçekleşmesine yönelik görüşleri incelenmiştir. Nitel araştırma yaklaşımının kullanıldığı bu çalışmada, Recep Tayyip Erdoğan Üniversitesi Eğitim Fakültesi'nde birinci sınıfta öğrenim gören, zorunlu dersler arasında yer alan Eğitim Sosyolojisi dersini alan öğrencilerden gönüllü olanlarla görüşme yapılmıştır. Öğrencilere imkân ve fırsat eşitliğinin gerçekleşmesini etkileyen ekonomik, coğrafi, toplumsal ve siyasal faktörler, Türk milli eğitimin temel ilkelerinin imkân ve fırsat eşitliğinin gerçekleşmesine yönelik etkisi, imkân ve fırsat eşitliğinin gerçekleşmesini etkileyen salgın sürecinde uzaktan eğitime yönelik sorular sorulmuştur.

Elde edilen veriler içerik analizine tabi tutularak sonuçlar sunulmuştur. Çalışmada ulaşılan sonuçlardan bazıları şunlardır: Öğrencilerin yaklaşık beşte dördünün görüşüne göre Türk eğitim sisteminde imkân ve fırsat eşitliği gerçekleşmektedir. Öğrencilerin görüşlerine göre ekonomik, coğrafi, toplumsal ve siyasal faktörler imkân ve fırsat eşitliğinin gerçekleşmesini etkilemektedir. Öğrencilerin büyük çoğunluğuna göre eğitim politikaları eğitimde imkân ve fırsat eşitliğini etkilemektedir. Öğrencilerin büyük çoğunluğuna göre özel eğitime ve korunmaya muhtaç çocukları yetiştirmek için özel tedbirler alınmaktadır. Öğrencilerin yaklaşık tamamına yakını göre salgın sürecinin tüm eğitim kademelerinde eğitimde imkân ve fırsat eşitliğini olumsuz etkilenmiştir.

Anahtar Kelimeler: Eğitim fakültesi, öğrenci görüşleri, imkân ve fırsat eşitliği, eğitim sosyolojisi, eğitim politikası.

\footnotetext{
${ }^{1}$ Bu çalışma; Kosova, Prizren'de 12-14 Aralık 2021 tarihilerinde düzenlenen II. Uluslararası Eğitimde Yenilikçi Araştırmalar Kongresi (ICIRE 2021),nde aynı adla sunulan bildirinin genişletilmiş halidir.
} 
To cite this article: Tuna, C. (2021). Opinions of Education Faculty Students on Realization of Equal

Opportunities and Opportunities in the Turkish Education System. Kosovo Educational Research Journal, 2(3). 2-28.

\title{
Opinions of Education Faculty Students on Realization of Equal Opportunities and Opportunities in the Turkish Education System
}

\author{
Cem TUNA*
}

Recep Tayyip Erdoğan Üniversity, TURKEY

\begin{abstract}
In this study, the views of the education faculty students regarding the realization of opportunity and equality of opportunity in the Turkish education system were examined. In this study, in which the qualitative research approach was used, interviews were conducted with volunteers from the first-year students who took the Sociology of Education course, which is among the compulsory courses at the Faculty of Education of Recep Tayyip Erdogan University. Students were asked questions about the economic, geographical, social and political factors affecting the realization of equality of opportunity and opportunity, the effect of the basic principles of Turkish national education on the realization of equality of opportunity and opportunity, and distance education during the epidemic that affected the realization of equality of opportunity and opportunity.
\end{abstract}

The obtained data were subjected to content analysis and the results were presented. Some of the results reached in the study are as follows: According to the opinion of approximately four-fifths of the students, equality of opportunity and opportunity is realized in the Turkish education system. According to the students' views, economic, geographical, social and political factors affect the realization of opportunity and equality of opportunity. According to the vast majority of students, education policies affect the equality of opportunity and opportunity in education. According to the majority of students, special measures are taken to raise children in need of special education and protection. According to almost all of the students, the equality of opportunity and opportunity in education at all educational levels of the epidemic process was adversely affected.

Keywords: Education faculty, student opinions, opportunity and equality of opportunity, sociology of education, education policy.

\section{Giriş}

Türkiye Cumhuriyeti Anayasası'nda kanun önünde eşitlik ilkesi düzenlenmiştir. Anayasanın onuncu maddesine göre "Herkes, dil, ırk, renk, cinsiyet, siyasi düşünce, felsefi inanç, din, mezhep ve benzeri sebeplerle ayırım gözetilmeksizin kanun önünde eşittir” (Arslan ve Kayançiçek, 2010, 39). Bu ilke eğitim alanında sosyal haklar arasında bulunan eğitim ve öğrenim hakkı ve ödevi 
olarak yer almıştır. "Kimse, eğitim ve öğrenim hakkından yoksun bırakılamaz. Öğrenim hakkının kapsamı kanunla tespit edilir ve düzenlenir"(Arslan ve Kayançiçek, 2010, 71).

Genel olarak dört tür eğitim eşitliğinden söz edilebilir (Tezcan, 2018, 131 vd):

- Herkese en üst basamağa kadar öğretim sağlamak,

- Herkese belirli düzeyde bir asgarî öğrenim hakkının sağlanması,

- Her bireyin kendi yetenek ve potansiyelinin tamamından yararlanmasını sağlayan bir öğrenime kavuşturulması,

- Eğitimde firsatlardan daha fazla bireyin yararlanmasının sağlanması.

İmkân ve firsat eşitliği; eğitimsel kaynaklara ulaşabilme ya da onlardan yararlanabilme eşitliğini ifade eder. Tüm öğrencilerin yeteneklerini en uygun biçimde geliştirmede eşit şansa sahip olmalarıdır (Tezcan, 2018, 131; Celkan, 1991). Anayasa imkân ve firsat eşitliği konusunda "Devlet, maddî imkânlardan yoksun başarılı öğrencilerin, öğrenimlerini sürdürebilmeleri amacıyla burslar ve başka yollarla gerekli yardımları yapar. Devlet, durumları sebebiyle özel eğitime ihtiyacı olanları topluma yararlı kılacak tedbirleri alır"(Madde 42/6) düzenlemesini getirmiştir (Arslan ve Kayançiçek, 2010, 72).

Eğitimde imkân ve firsat eşitliği, bireylerin eğitimden yararlanması amacıyla ülke, bölge, okul, sınıf düzeyinde verilecek hizmetlerin beklenen ve yeterli ölçülerde olmasıyla mümkün olabilir. Bu hizmetlerin yeterince verilememesine neden olan faktörler bulunmaktadır. Bunlar; ekonomik, coğrafi, toplumsal ve siyasal faktörler olarak sıralanabilir (Gürbüztürk, 2019, 215; Tezcan, 2018, 134 vd.; Doğan, 2007, 270 vd.). Ekonomik faktörler arasında ailenin geliri ve devletin ekonomik gücü yer almaktadır. Coğrafi faktörler arasında; iklim ve yeryüzü şekilleri, yerleşim düzeni ve bölgesel farklılaşma boyutları bulunmaktadır. Toplumsal faktörler olarak; cinsiyet, din, dil, etnik grup, nüfus boyutları söz konusudur. Siyasal faktörler arasında; her ülkenin benimsediği siyasal rejime göre bir eğitim politikası bulunmaktadır. Yetiştirilmek istenen insan tipi, bütçeden eğitime ayrılan pay, eğitime yatırım, öğretmen istihdamı, öğrenci başına ayrılan pay gibi unsurlar siyasal faktörler olarak karşımıza çıkmaktadır (Gürbüztürk, 2019, 215 vd; Tezcan, 2018, 134 vd).

Eğitimde imkân ve firsat eşitliği Milli Eğitim Temel Kanunu'nda yerini almıştır. Buna göre "Kadın erkek ayrımı yapılmaksızın herkes aynı haklara sahiptir. Maddi imkânlardan yoksun bireylere yurt, kredi, burs vs yollarla gerekli yardımlar yapılır" (Akyüz, 2020, 376; Çelikkaya, 
1998, 149). Bunun yanında eğitimde genellik ve eşitlik, yöneltme, eğitim hakkı ilkeleri de eğitimde imkân ve firsat eşitliği ile ilgilidir.

Yüksek Öğretim Kurumu (YÖK), 2018 yılında öğretmen yetiştirme lisans programlarını yenilemiştir. Bu programda birinci sınıfın dersleri arasında Eğitim Sosyolojisi yer almaktadır (YÖK, 2021). Dersin içeriğinde firsat eşitliği bulunmakta, dersin amaçları arasında sosyolojinin eğitime katkıları, eğitim sorunlarının anlaşılmasına ve çözümlenmesine yapacağı katkı konusunda farkındalık oluşturma yer almaktadır. Eğitim fakültelerinde bu ders zorunlu dersler arasında bulunmakta, öğrenciler birinci sınıfta bu dersi görmektedirler. İmkân ve firsat eşitliği konusunu alan ve öğrenen z kuşağı adı verilen öğrencilerin bu konu ile ilgili görüşleri önem arz etmektedir.

Bu çalışmada 2020-2021 Eğitim ve Öğretim Yılı'nda Recep Tayyip Erdoğan Üniversitesi Eğitim Fakültesi'nde Eğitim Sosyolojisi dersini alan öğrencilerin Türk eğitim sisteminde imkân ve firsat eşitliğinin gerçekleşmesine yönelik görüşleri incelenmiştir.

Araştırmanın temel amacı doğrultusunda aşağıdaki sorulara cevap aranmıştır:

1. Öğrencilerin imkân ve firsat eşitliğinin gerçekleşmesini etkileyen ekonomik, coğrafi, toplumsal ve siyasal faktörlere yönelik görüşleri nelerdir?

2. Öğrencilerin Türk milli eğitimin temel ilkelerinin, imkân ve firsat eşitliğinin gerçekleşmesine yönelik etkisi hakkında görüşleri nelerdir?

3. Öğrencilerin imkân ve firsat eşitliğinin gerçekleşmesini etkileyen salgın sürecinde uzaktan eğitime yönelik görüşleri nelerdir?

\section{YÖNTEM}

$\mathrm{Bu}$ çalışma nitel araştırma yaklaşımlarından nitel durum çalışmasıdır. Nitel araştırmalar, verilerin sayılar biçiminde olmadığı; gözlem, görüşme ve doküman analizi gibi nitel veri toplama yöntemlerinin kullanıldığı; algıların ve olayların doğal ortamlarında gerçekçi ve bütüncül olarak ortaya konulmasına çalışılan araştırmalardır (Yıldırım ve Şimşek, 2011). Burada Eğitim Sosyolojisi dersini seçen öğrencilerin Türk eğitim sisteminde imkân ve firsat eşitliğinin gerçekleşmesine yönelik görüşlerini saptamak amacıyla nitel durum araştırması yapılmıştır. Verilerin analizinde betimsel analiz tekniği kullanılmıştır. Betimsel analiz, toplanan verilerin, daha önceden belirlenmiş temalara göre özetlenip yorumlanmasına dayanır. Veriler, araştırma 
sorularının ortaya koyduğu temalara göre organize edilebileceği gibi görüşme ve gözlem süreçlerinde kullanılan sorular ya da boyutlar dikkate alınarak da sunulabilir. $\mathrm{Bu}$ süreçte katılımcıların görüşlerine de doğrudan yer verilir (Yıldırım ve Şimşek, 2011). Bu kapsamda araştırmada öğrencilere çevrimiçi anket uygulanmış ve veriler analiz edilmiştir. Bu konuda Recep Tayyip Erdoğan Üniversitesi Sosyal ve Beşerî Bilimler Etik Kurulu'ndan izin alınmıştır. İzin belgesi ekte sunulmuştur.

Çalışma grubu 2020-2021 Eğitim ve Öğretim Y1lı'nda Recep Tayyip Erdoğan Üniversitesi Eğitim Fakültesi’nde Eğitim Sosyolojisi dersini seçen 61 gönüllü öğrenciden oluşmaktadır.

Tablo 1: Katılımcıların Cinsiyetlerine Göre Dağılımı

\begin{tabular}{lcc}
\hline Cinsiyet & Frekans & Yüzde \\
\hline Kadın & 51 & 83.6 \\
Erkek & 10 & 16.4 \\
Toplam & 61 & 100 \\
\hline
\end{tabular}

Altmış bir katılımcının cinsiyete göre, 51 'i kadın (\% 83.6), 10’u erkek (\% 16.4) öğrencidir. Eğitim Fakültesine kayıtlı öğrencilerin üçte ikisi kadın öğrencilerden oluşmaktadır. Çalışmaya katılanların yaklaşık beşte dördünden fazlasını kadın katılımcılar, beşte birinden azını erkek katılımcılar oluşturmaktadır.

Tablo 2: Anabilim Dallarına Göre Dağılım

\begin{tabular}{lcc}
\hline Bölüm & Frekans & Yüzde \\
\hline Sosyal Bilgiler Öğretmenliği & 26 & 42.6 \\
Türkçe Öğretmenliği & 23 & 37.7 \\
Fen Bilgisi Öğretmenliği & 5 & 8.2 \\
Sınıf Öğretmenliği & 4 & 6.6 \\
Resim İş Öğretmenliği & 2 & 3.3 \\
Rehberlik/ Psikolojik Danışma & 1 & 1.6 \\
Toplam & 61 & 100 \\
\hline
\end{tabular}

Katılımcılar anabilim dallarına göre; Sosyal Bilgiler Öğretmenliği 26 (\% 42.6), Türkçe Öğretmenliği 23 (\% 37.7), Fen Bilgisi Öğretmenliği 5 (\% 8.2), Sınıf Öğretmenliği 4 (\% 6.6), 
Resim İş Öğretmenliği 2 (\% 3.3) ve Rehberlik ve Psikolojik Danışma 1 (\%1.6) şeklinde dağılım göstermektedir.

Araştırmada yarı yapılandırılmış görüşme formu kullanılmıştır. Yarı yapılandırılmış görüşme; verilerin hızlı kodlanmasına ve analiz edilmesine imkân tanıması, katılımcıların verdikleri bilgiler arasında benzerlik ve farklılıkları karşılaştırmaya yardımcı olması gibi özellikleri nedeniyle kullanılmıştır (Büyüköztürk ve diğerleri, 2016). Araştırmada öğretmen adaylarına biri temel olmak üzere yirmi soru sorulmuş ve cevaplamaları istenmiştir.

Konuyla ilgili olarak eğitim sosyolojisi ve eğitim yönetimi alanlarında çalışan üç öğretim elemanından görüşme formundaki soruların açık ve anlaşılır olup olmaması, araştırılan konuyu kapsayıp kapsamaması, araştırılan verileri sağlayıp sağlamaması açılarından kontrol etmeleri istenmiştir. Sonuçta uzmanlar tarafından soru maddelerinin geçerliliği saptanmış ve yeterli görülmüştür. Mayıs 2021'de bu dersi seçen beş öğrenciye pilot uygulama yapılmış, alınan geri bildirimler doğrultusunda veri toplama aracına son şekli verilmiştir.

Salgın hastalık sürecinde çevrimiçi olarak görüşme tekniği ile verilere ulaşılan bu araştırmada verilerinin çözümlenmesinde içerik analizi ve betimsel analiz tekniği kullanılmış, bulgular uygun görülen ve gerekli olan yerlerde nicelleştirilerek (sayı kullanılarak) sunulmuştur. Nitel bulgular analize açıklık getirmek, güvenirliği arttırmak için nicel ifadeler kullanılarak betimlenmeye çalışılmıştır (Yı1dırım ve Şimşek, 2011). Görüşmelerde katılımcıların dile getirdiği ifadelerden bazıları doğrudan alıntı olarak kullanılmıştır. Katılımcıların gerçek ismi yerine Ö1 (Öğrenci 1) şeklinde kod numaraları kullanılmıştır. 61 öğrenciye kod numarası verilmiştir.

\section{BULGULAR}

Katılımcıların görüşme formundaki sorulara verdikleri cevaplara göre elde edilen bulgular aşağıda sunulmuştur.

Tablo 3: 1-Eğitimde imkân ve fırsat eşitliğini ekonomik faktörler etkilemektedir.

\begin{tabular}{lcc}
\hline Görüş & Frekans & Yüzde \\
\hline Kesinlikle Katılıyorum & 40 & 65.6 \\
Katılıyorum & 17 & 27.9 \\
Kısmen Katılıyorum & 2 & 3.3
\end{tabular}


Katılmıyorum

Kesinlikle Katılmıyorum

Toplam
2

$-$

61
3.3

100

Tablo 3'e göre; katılımcılarım 40'1 (\%65.6) bu soruya kesinlikle katılıorum, 17'si (\%27.9) katılıyorum, 2’si (\%3.3) kısmen katılıyorum görüşünü belirtmişlerdir. 2 (\%3.3) katılımc1 ise katılmıyorum görüşündedir. Buna göre katılımcıların büyük çoğunluğu eğitimde imkân ve firsat eşitliğini ekonomik faktörlerin etkilediği görüşündedir. Katılımcıların doğrudan örnek cümleleri şu şekildedir:

Bir ögretmen adayı olarak ülkemizde özellikle maddi durumu ve hayat şartları gerekçesiyle eğitim/öğretim durumunda sıkıntı yaşayan öğrencilerin, tespit edilme oranının daha yüksek olmasını umut ediyorum (Ö36).

Tablo 4: 2-Ailenin gelir düzeyi eğitimde imkân ve fırsat eşitliğini olumlu ya da olumsuz etkilemektedir.

\begin{tabular}{lccc}
\hline Görüş & Frekans & Yüzde \\
\hline Kesinlikle Katılıyorum & 38 & 62.3 \\
Katılıyorum & 18 & & 29.5 \\
Kısmen Katılıyorum & & 5 & 8.2 \\
Katılmıyorum & - & - \\
Kesinlikle Katılmıyorum & - & - \\
Toplam & 61 & 100 \\
\hline
\end{tabular}

Tablo 4'e göre; katılımcılarım 38'i (\%62.3) bu soruya kesinlikle kat1lıorum, 18'i (\%29.5) katılıyorum, 5'i (\%8.2) kısmen katılıyorum görüşünü belirtmişlerdir. Buna göre katılımcıların büyük çoğunluğu ailenin gelir düzeyi eğitimde imkân ve firsat eşitliğini olumlu ya da olumsuz etkilediği görüşündedir. Katılımcıların doğrudan örnek cümleleri şu şekildedir:

Artık Günümüzde özel okullar arasında bile imkân ve firsat eşitliği konusunda farklılıklar söz konusu iken bu konuyu sadece devlet okulları baz alınarak tartışmamak gerekiyor aslında. Maalesef ki üzülerek belirtiyorum yaşadığımız bu dönem zengini daha zengin, fakiri daha fakir yapmış ve bu kişilerin nesilleri ulaşabilirdik konusunda bambaşka eğitim şartları ile karşı karşıya 
kalmıştır. Hatta iki çeşit özel okul oluştu. Artık birincisi gerçekten eğitimi ile öne çıkan başarılı okul ikincisi fiziki şartlart iyi olup içi boş özel okul. Ve asıl sorun ise bu ikisini de tercih edemeyen milyonlarca ailenin alması. Yaşadığımız bu dönem güçlü olanların dönemi. Zor elde etmiş bi kardeşiniz olarak Kimse bana çılkp güçlülerin dünyasında eşitlikten bahsetmesin (Ö9).

Türkiye'de ki eğitim sisteminde firsat eşitliği aldatmacadan ibarettir. Tipkı çatışmacı kuramın vurguladı̆̆ı gibi. Bu eşitsizlikten ise en çok alt tabakanın çocukları etkilenmektedir. Parası olan aileler çocuklarına daha kaliteli eğitim adı altında özel okullara gönderebilirken, yoksul ya da fakir ailelerin çocukları bu imkândan faydalanamamaktadır. Tabi bu özel okullarda ki para/not ilişskisi de değerlendirilmelidir. Bunun dışında okullar alt düzey bir toplumsal sınıfa mensup çocuğu üst düzey sinıfa çıkarmayı vaat etse de bu çoğunlukla gerçekleşmemektedir /Ö35).

Tablo 5: 3-Ailenin eğitim düzeyi yüksekse çocuklar eğitimde imkân ve fırsat eşitliğinden daha çok yararlanmaktadır.

\begin{tabular}{lcc}
\hline Görüş & Frekans & Yüzde \\
\hline Kesinlikle Katılıyorum & 23 & 37.7 \\
Katılıyorum & 26 & 42.6 \\
Kısmen Katılıyorum & 9 & 14.8 \\
Katılmıyorum & 2 & 3.3 \\
Kesinlikle Katılmıyorum & 1 & 1.6 \\
Toplam & 61 & 100 \\
\hline
\end{tabular}

Tablo 5'e göre; katılımcılarım 23'ü (\%37.7) bu soruya kesinlikle katılıyorum, 26's1 (\%42.6) katılıyorum, 9'u (\%8.2) kısmen katılıyorum görüşünü belirtmişlerdir. 2 (\%3.3) katılımc1 katılmıyorum, 1 (1.6) katılımcı ise kesinlikle katılmıyorum görüşündedir. Buna göre katılımcıların büyük çoğunluğu ailenin eğitim düzeyi yüksekse çocuklar eğitimde imkân ve firsat eşitliğinden daha çok yararlanmaktadır görüşündedir. Katılımcıların doğrudan örnek cümleleri şu şekildedir: Özel okulların ve özel kursların ya kapatılması gerekiyor ya da bu kurumların sikı sıkıya denetlenmesi ve takip edilmesi gerekiyor. Özel okula giden ögrrenciye slnava yönelik sorular, çalışmalar hazırllyorlar buna bir de ek kurslar takviye ediyorlar. Böyle bir çocuğun bizim eğitim sistemimizde başarısız olması söz konusu bile olamayabilir. Ama devlet okullarında az sayıda ders 
saati olması ve davranış bozukluğu gösteren öğrenciler gibi olumsuz faktörlerin bir araya gelmesi ile zaten kaynak sorunu yaşayan ögrenciler başarısız olmakta (Ö23).

Özel okullar kapatılıp onlarda devlet okuluna dönüştürülmesi ve üst düzey ögretmenlerin çocuklar için eşit eğitim vermesi gerekir. Eğitimin paralısı olmaması gerekir (Ö16).

Özel okullar bu uçurumu daha fazla açıyor. Devlet okullarından daha fazla imkâna sahip oldukları için bu ilkeyle çelişiyor. Aynı zamanda özel üniversitelerde bu ilkeyi olumsuz etkiliyor (Ö37).

Tablo 6: 4-Eğitimde imkân ve fırsat eşitliğini coğrafi faktörler etkilemektedir.

\begin{tabular}{|c|c|c|}
\hline Görüş & Frekans & Yüzde \\
\hline Kesinlikle Katılıyorum & 26 & 42.6 \\
\hline Katılıyorum & 28 & 45.9 \\
\hline Kısmen Katılıyorum & 4 & 6.6 \\
\hline Katılmıyorum & 3 & 4.9 \\
\hline Kesinlikle Katılmıyorum & - & - \\
\hline Toplam & 61 & 100 \\
\hline
\end{tabular}

Tablo 6'ya göre; katılımcılarım 26'sı (\%42.6) bu soruya kesinlikle katılıorum, 28'i (\%45.9) katılıyorum, 4’ü (\%6.6) kısmen katılıyorum görüşünü belirtmişlerdir. 3 (\%4.9) katılımc1 ise katılmıyorum görüşündedir. Buna göre katılımcıların büyük çoğunluğu eğitimde imkân ve firsat eşitliğini coğrafi faktörlerin etkilediği görüşündedir. Katılımcıların doğrudan örnek cümleleri şu şekildedir:

Hayat şartları zor olan bölgelerde yaşayan öğrencilerin dezavantajlarını avantaja çevirmek gerekiyor (Ö42). Her şey çok daha güzel olabilir. Bütün şehirlerdeki öğrenciler hiçbir ayrım yapılmaksızın en temelden alınarak ĕgitilmeli ve ögretilmelidir (Ö42).

Her ilde devlet kadrosundan görevliler olabilir ve bu görevliler sayesinde eğitimde meydana gelen olumsuzluklar araştırılıp devletin gerekli mecralarına iletilebilir. Özellikle kırsal kesimde yaşayan çocuklar için özel çalışmalar yapılabilir (61).

Tablo 7: 5-Köylerde çocukların tarlada, bağda, hayvancılık işlerinde çalışması eğitimde imkân ve fırsat eşitliğini etkilemektedir. 


\begin{tabular}{|c|c|c|}
\hline Görüş & Frekans & Yüzde \\
\hline Kesinlikle Katılıyorum & 32 & 52.5 \\
\hline Katılıyorum & 22 & 36.1 \\
\hline Kısmen Katılıyorum & 5 & 8.2 \\
\hline Katılmıyorum & 2 & 3.3 \\
\hline Kesinlikle Katılmıyorum & - & - \\
\hline Toplam & 61 & 100 \\
\hline
\end{tabular}

Tablo 7'ye göre; katılımcılarım 32'si (\%52.5) bu soruya kesinlikle katılıyorum, 22'si (\%36.1) katılıyorum, 5’i (\%8.2) kısmen katılıyorum görüşünü belirtmişlerdir. 2 (\%3.3) katılımcı ise katılmıyorum görüşündedir. Buna göre katılımcıların büyük çoğunluğu köylerde çocukların tarlada, bağda, hayvancılık işlerinde çalışması eğitimde imkân ve firsat eşitliğini etkilediği görüşündedir. Katılımcıların doğrudan örnek cümleleri şu şekildedir:

Öğrencilerin yeteneklerine göre ĕgitim verilmelidir. Fırsatlar her yerde her zaman eşit olmuyor ya da hiçbir firsat elde edilemiyor. Her yerde eğitimin en yüksek imkânları sunulmalı köy, şehir farketmemeli. Ülkemizdeki her çocuk bunu hak ediyor (Ö24).

Eğitim sistemimiz merkezi bir sistem olarak işlev gördüğünden kirsal kesimde eğitim gören ögrencilerin sahip oldukları imkânların daha iyi olabilmesi için gerekli çalışmaların arttırılması gerektiğini düşünüyorum. Böylece imkân ve firsat eşitliği sağlanarak en azından merkezde eğitim gören ögrrencilerle aralarındaki eşitsizlik minimum düzeye indirilebilir (Ö43).

Tablo 8: 6-Kadın-erkek ayrımı kız çocuklarının eğitimini engellemektedir.

\begin{tabular}{|c|c|c|}
\hline Görüş & Frekans & Yüzde \\
\hline Kesinlikle Katılıyorum & 25 & 41 \\
\hline Katılıyorum & 11 & 19.7 \\
\hline Kısmen Katılıyorum & 17 & 27.9 \\
\hline Katılmıyorum & 5 & 8.2 \\
\hline Kesinlikle Katılmıyorum & 2 & 3.3 \\
\hline Toplam & 61 & 100 \\
\hline
\end{tabular}

Tablo 8'e göre; katılımcılarım 25'i (\%41) bu soruya kesinlikle katılıyorum, 11'i (\%19.7) katılıyorum, 17’si (\%27.9) kısmen katılıyorum görüşünü belirtmişlerdir. 5 (\%8.2) katılımcı katılmıyorum, 2 (3.3) katılımcı ise kesinlikle katılmıyorum görüşündedir. Buna göre katılımcıların 
yaklaşık dörtte üçü kadın-erkek ayrımının kı çocuklarının eğitimini engellemektedir görüşündedir. Yaklaşık dörtte bir katılımcı ise bu görüşe katılmamaktadır. Katılımcıların doğrudan örnek cümleleri şu şekildedir:

Ĕ̆itimde imkân ve firsat eşitliğinin tam olarak să̆lanabileceğini düşünmüyorum. İmkân ve firsat eşitsizliğini en aza indirmeye yönelik çalışmalar yapılmalıdır (Ö60).

Tablo 9: 7-Resmi dil dışında kalan yerel diller eğitimde imkân ve fırsat eşitliğini olumsuz etkileyebilmektedir.

\begin{tabular}{|c|c|c|}
\hline Görüş & Frekans & Yüzde \\
\hline Kesinlikle Katılıyorum & 6 & 9.8 \\
\hline Katılıyorum & 13 & 21.3 \\
\hline Kısmen Katılıyorum & 25 & 41 \\
\hline Katılmıyorum & 14 & 23 \\
\hline Kesinlikle Katılmıyorum & 3 & 4.9 \\
\hline Toplam & 61 & 100 \\
\hline
\end{tabular}

Tablo 9'a göre; katılımc1larım 6's1 (\%9.8) bu soruya kesinlikle katılıorum, 13'ü (\%21.3) katılıyorum, 25'i (\%41) kısmen katılıyorum görüşünü belirtmişlerdir. 14 (\%23) katılımcı katılmıyorum, 3 (4.9) katılımcı ise kesinlikle katılmıyorum görüşündedir. Buna göre katılımcıların yaklaşık beşte üçü resmi dil dışında kalan yerel diller eğitimde imkân ve firsat eşitliğini olumsuz etkileyebilmektedir görüşündedir. Yaklaşık beşte iki katılımcı ise bu görüşe katılmamaktadır. Katılımcıların doğrudan örnek cümleleri şu şekildedir:

Elbette bu konuda çalışmalar yapılmalı. Örneğin anaokulu, ana sınıfı imkânları arttırılabilir (Ö33).

Tablo 10: 8-Okullarda yeterli sayı ve nitelikte öğretmen olmaması eğitimde imkân ve fırsat eşitliğini etkilemektedir.

\begin{tabular}{|c|c|c|}
\hline Görüş & Frekans & Yüzde \\
\hline Kesinlikle Katılıyorum & 25 & 41 \\
\hline Katılıyorum & 29 & 47.5 \\
\hline Kısmen Katılıyorum & 4 & 6.6 \\
\hline Katılmıyorum & 2 & 3.3 \\
\hline Kesinlikle Katılmıyorum & 1 & 1.6 \\
\hline
\end{tabular}


Tablo 10'a göre; katılımcılarım 25'i (\%41) bu soruya kesinlikle katıllyorum, 29'u (\%47.5) katılıyorum, 4'ü (\%6) kısmen katıllyorum görüşünü belirtmişlerdir. 2 (\%3.3) katılımcı katılmıyorum, 1 (1.6) katılımcı ise kesinlikle katılmıyorum görüşündedir. Buna göre katılımcıların büyük çoğunluğu okullarda yeterli sayı ve nitelikte öğretmen olmamasının eğitimde imkân ve firsat eşitliğini etkilediği görüşündedir. Katılımcıların doğrudan örnek cümleleri şu şekildedir:

Öğretmenler sadece ögrrencilerin adını soyadını ve notlarını bilmekle yetinmemeli, ögrencilerle kendi çocuğuyla ilgilenir gibi ilgilenmeli ve öğrencilerin ailesel, ekonomik, sosyal sıkıntılarına çözüm getirebilmeli. Sinıflarda ekonomik geliri düşük çocuklara sanki tek sorun buymuş gibi montu, ayakkabıyı herkesin gözü içinde verip rencide etmek hoş bir davranış değil. Yapılan yardımlar bir emir sonucunda değil öğretmenlerin kendi çabası ve isteğiyle olmall. Günümüzde ne yazık ki öğretmenler tüm öğrencilerin eşit imkânlara sahip olduklarını düşünüyor. Çocuklardan fotokopi parası, yahut tuvalet kă̆ıdı parası almak çok absürt bir harekettir. Rencide edici bir şekilde bu paraları toplayıp isimlerinin yanına artı eksi koymak ise çok daha absürt bir harekettir. Çocuklardan alınan tek kuruşun dahi, fişlerle nereye harcandiğını gösterilmesi gerekiyor (Ö19).

Tablo 11: 9-Eğitim politikaları eğitimde imkân ve fırsat eşitliğini etkilemektedir.

\begin{tabular}{|c|c|c|}
\hline Görüş & Frekans & Yüzde \\
\hline Kesinlikle Katılıyorum & 25 & 41 \\
\hline Katılıyorum & 26 & 42.6 \\
\hline Kısmen Katılıyorum & 7 & 11.5 \\
\hline Katılmıyorum & 3 & 4.9 \\
\hline Kesinlikle Katılmıyorum & - & - \\
\hline Toplam & 61 & 100 \\
\hline
\end{tabular}

Tablo 11'e göre; katılımc1larım 25's1 (\%41) bu soruya kesinlikle kat1liyorum, 26's1 (\%42.6) katılıyorum, 7'si (\%11.5) kısmen katılıyorum görüşünü belirtmişlerdir. 3 (\%4.9) katılımcı ise katılmıorum görüşündedir. Buna göre katılımcıların büyük çoğunluğu eğitim politikaları eğitimde imkân ve fırsat eşitliğini etkilediği görüşündedir. Katılımcıların doğrudan örnek cümleleri şu şekildedir:

Ağır dil bilgisi kuralları, karmaşı k matematik teorilerini müfredatın daha ileriki yaş gruplarına kaydırmalı, okuduğunu anlayabilen güzel cümleler kurabilen, farkındalık yeteneği gelişmiş ve tıpkı Japonlar gibi ülkesine en iyi şekilde hizmet vermek isteyen nesiller yetişstirmeliyiz (Ö43). 
Devlet politikalarını değiştirmeli, her şeyden önce insanı ele almalı. İnsana dĕger vermeli. Gelecek korkusu yaşamamalıyı (Ö11).

Tablo 12: 10-Özel eğitime ve korunmaya muhtaç çocukları yetiştirmek için özel tedbirler alınmaktadır.

\begin{tabular}{|c|c|c|}
\hline Görüş & Frekans & Yüzde \\
\hline Kesinlikle Katılıyorum & 22 & 36.1 \\
\hline Katılıyorum & 26 & 42.6 \\
\hline Kısmen Katılıyorum & 8 & 13.1 \\
\hline Katılmıyorum & 4 & 6.6 \\
\hline Kesinlikle Katılmıyorum & 1 & 1.6 \\
\hline Toplam & 61 & 100 \\
\hline
\end{tabular}

Tablo 12'ye göre; katılımcılarım 22'si (\%36.1) bu soruya kesinlikle katılıyorum, 26's1 (\%42.6) katılıyorum, 8'i (\%13.1) kısmen katılıyorum görüşünü belirtmişlerdir. 4 (\%6.6) katılımcı katılmıyorum, 1 (1.6) katılımcı ise kesinlikle katılmıyorum görüşündedir. Buna göre katılımcıların büyük çoğunluğu özel eğitime ve korunmaya muhtaç çocukları yetiştirmek için özel tedbirler alınmaktadır görüşündedir. Katılımcıların doğrudan örnek cümleleri şu şekildedir:

Öğrenim gören öğrencilerin durumları analiz edilip belli faktörlere göre onları gruplandırıp ona göre ĕgitim politikaları uygulanmalıdır (Ö54).

Tablo 13: 11-Eğitim kurumları dil, ırk, cinsiyet, engellilik ve din ayırımı gözetilmeksizin herkese açıktır. Eğitimde hiçbir kişiye, aileye, zümreye veya sınıfa imtiyaz tanınmamaktadır.

\begin{tabular}{|c|c|c|}
\hline Görüş & Frekans & Yüzde \\
\hline Kesinlikle Katılıyorum & 21 & 34.4 \\
\hline Katılıyorum & 23 & 37.7 \\
\hline Kısmen Katılıyorum & 10 & 16.4 \\
\hline Katılmıyorum & 3 & 4.9 \\
\hline Kesinlikle Katılmıyorum & 4 & 6.6 \\
\hline Toplam & 61 & 100 \\
\hline
\end{tabular}

Tablo 13'e göre; katılımcılarım 21'i (\%34.4) bu soruya kesinlikle katılıyorum, 23’ü (\%37.7) katılıyorum, 10’u (\%16.4) kısmen katılıyorum görüşünü belirtmişlerdir. 3 (\%4.9) katılımcı 
katılmıyorum, 4 (\%6.6) katılımcı ise kesinlikle katılmıyorum görüşündedir. Buna göre katılımcıların yaklaşık beşte dördü eğitimde eşitlik ilkesine uyulduğu görüşündedir. Yaklaşık beşte bir katılımcı ise bu görüşe katılmamaktadır. Katılımcıların doğrudan örnek cümleleri şu şekildedir: Öğrencilerin ĕgitim hayatı sadece ders başarısı olarak dĕgerlendirilmemelidir. Okul ĕgitim verilen tek yer olmamalıdır. Örneğin köyde yaşayan çocuklar topraktan anllyorsa onlar bu yönde eğitilmeli ya da onlar arkadaşlarına bildiklerini doğada bizzat göstermeli. Klsacası eksiklerimizi tamamlamak için herkes kendi içindeki artıları bir araya getirmelidir. Öncelikli amaç iyi insan yetiştirmek olmalıdır (Ö29).

Tablo 14: 12-Öğrenciler, eğitimleri süresince, ilgi, istidat ve kabiliyetleri ölçüsünde ve doğrultusunda çeşitli programlara veya okullara yöneltilerek yetiştirilirler.

\begin{tabular}{lcc}
\hline Görüş & Frekans & Yüzde \\
\hline Kesinlikle Katılıyorum & 7 & 11.5 \\
Katılıyorum & 19 & 29.5 \\
Kısmen Katılıyorum & 20 & 32.8 \\
Katılmıyorum & 11 & 18 \\
Kesinlikle Katılmıyorum & 5 & 8.2 \\
Toplam & 61 & 100 \\
\hline
\end{tabular}

Tablo 14'e göre; katılımcılarım 7'si (\%11.5) bu soruya kesinlikle katılıyorum, 19'u (\%29.5) katılıyorum, 20’si (\%32.8) kısmen katılıyorum görüşünü belirtmişlerdir. 11 (\%18) katılımcı katılmıyorum, 5 (\%8.2) katılımcı ise kesinlikle katılmıyorum görüşündedir. Buna göre katılımcıların yaklaşık yarısından biraz fazlası eğitimde yöneltme ilkesine uyulduğu görüşündedir. Yaklaşık yarıdan biraz az katılımcı ise bu görüşe katılmamaktadır. Katılımcıların doğrudan örnek cümleleri şu şekildedir:

Her öğrenci tektir biriciktir. Her öğrencinin ilgi istek ve yeteneklerine göre ĕ̆itim hizmeti săglanmalıdır (Ö8).

Türk eğitim sisteminde imkân ve firsat eşitliği să̆lanmaya çalışlllyor ama sağlıklı temeller üzerine kurulmadığı için çözüm getirmediğini düşünüyorum (Ö55).

Tablo 15: 13-Yasalara göre ilköğretim ve ortaöğretim görme hakkından Türk vatandaşları yararlanmaktadır. 


\begin{tabular}{lcc}
\hline Görüş & Frekans & Yüzde \\
\hline Kesinlikle Katılıyorum & 22 & 36.1 \\
Katılıyorum & 24 & 39.3 \\
Kısmen Katılıyorum & 6 & 9.8 \\
Katılmıyorum & 8 & 13.1 \\
Kesinlikle Katılmıyorum & 1 & 1.6 \\
Toplam & 61 & 100 \\
\hline
\end{tabular}

Tablo 15'e göre; katılımcılarım 22'si (\%36.1) bu soruya kesinlikle kat1lıyorum, 24'ü (\%39.3) katılıyorum, 6’sı (\%9.8) k1smen kat1lıyorum görüşünü belirtmişlerdir. 8 (\%13.1) katılımc1 katılmıyorum, 1 (\%1.6) katılımcı ise kesinlikle katılmıyorum görüşündedir. Buna göre katılımcıların yaklaşık beşte dördü eğitim hakkı ilkesine uyulduğu görüşündedir. Yaklaşık beşte bir katılımcı ise bu görüşe katılmamaktadır. Katılımcıların doğrudan örnek cümleleri şu şekildedir: Şu an bile ülkemizde hala tam olarak bu eşitliğin să̆lanamadı̆̆ını ve bu konuda yapılan çalışmalara daha fazla önem verilmesini düşünüyorum. Eğitim insanlı̆̆ın geleceğini belirler (Ö21).

Herkesin başarılı ve iyi bir eğitim görebilmesi için imkân ve firsat eşitliği olmalıdır (Ö31).

Tablo 16: 14-Eğitimde kadın, erkek herkese fırsat ve imkân eşitliği sağlanmaktadır.

\begin{tabular}{|c|c|c|}
\hline Görüş & Frekans & Yüzde \\
\hline Kesinlikle Katılıyorum & 15 & 24.6 \\
\hline Katılıyorum & 28 & 45.9 \\
\hline Kısmen Katılıyorum & 13 & 21.3 \\
\hline Katılmıyorum & 3 & 4.9 \\
\hline Kesinlikle Katılmıyorum & 2 & 3.3 \\
\hline Toplam & 61 & 100 \\
\hline
\end{tabular}

Tablo 16'ya göre; katılımcılarım 15'i (\%24.6) bu soruya kesinlikle katıllyorum, 28'i (\%45.9) katılıyorum, 13’ü (\%21.3) kısmen katılıyorum görüşünü belirtmişlerdir. 3 (\%4.9) katılımcı katılmıyorum, 2 (\%3.3) katılımcı ise kesinlikle katılmıyorum görüşündedir. Buna göre katılımcıların yaklaşık beşte dördü eğitimde firsat ve imkân eşitliği ilkesine uyulduğu görüşündedir. Yaklaşık beşte bir katılımcı ise bu görüşe katılmamaktadır. Katılımcıların doğrudan örnek cümleleri şu şekildedir: 
Bana göre devlet okulları sabah 9'da derse başlayıp akşam 6'ya kadar eğitim ve ögretim vermeli. Aktivite ve rehberlik derslerine önem verilmeli, okullarda çok uygun bir fiyatta yemek verilmeli, matematik çözebilen robot çocuklar yetiştirmek yerine hayattaki birçok sorunla, durumla mücadele edebilen, analitik ve pratik zekâsını kullanabilen, enerjik hareketli çocuklar yetiştirmeliyiz (Ö52). İlkokul 1. sınıf ve lise sona kadar olan ĕgitim basamaklarında ĕgitim ögrencilerin imkân ve firsat eşitliği takip edilmeli ve üniversitede okuyan ögrencilere verilen burs firsatı arttırılmalıdır (Ö33).

Kız erkek fark etmeksizin, herkese eğitim konusunda yardım edilmesi gerektiğini düşünüyorum. Özellikle maddi yardımın ĕ̆itimi birçok açıdan etkilediğini belirtmek istiyorum. Bizzat yaşayan biri olarak, okuldan istenilen bir şey olunca veliler büyük tepkiler verebiliyor. Bu da ögrencileri olumsuz etkiliyor (Ö18).

Hiç bir şekilde eşitlik yok maddi imkânlar ve çevre de olan tanıdıklarınız sayesinde bir yerlere gelebiliyorsunuz (Ö37).

Tablo 17: 15-Maddi imkânlardan yoksun başarılı öğrencilerin en yüksek eğitim kademelerine kadar öğrenim görmelerini sağlamak amacıyla parasız yatılılı, burs, kredi ve başka yollarla gerekli yardımlar yapılmaktadır.

\begin{tabular}{|c|c|c|}
\hline Görüş & Frekans & Yüzde \\
\hline Kesinlikle Katılıyorum & 15 & 24.6 \\
\hline Katılıyorum & 29 & 47.5 \\
\hline Kısmen Katılıyorum & 14 & 23 \\
\hline Katılmıyorum & 2 & 3.3 \\
\hline Kesinlikle Katılmıyorum & 1 & 1.6 \\
\hline Toplam & 61 & 100 \\
\hline
\end{tabular}

Tablo 17'ye göre; katılımcılarım 15'i (\%24.6) bu soruya kesinlikle katılıyorum, 29'u (\%47.5) katılıyorum, 14’ü (\%23) kısmen katılıyorum görüşünü belirtmişlerdir. 2 (\%3.3) katılımc1 katılmıyorum, 1 (\%1.6) katılımcı ise kesinlikle katılmıyorum görüşündedir. Buna göre katılımcıların yaklaşık beşte dördü eğitimde imkân ve firsat eşitliği araçlarına uyulduğu görüşündedir. Yaklaşık beşte bir katılımcı ise bu görüşe katılmamaktadır. Katılımcıların doğrudan örnek cümleleri şu şekildedir: 
Ailelerin ekonomik durumu göz önünde tutularak çocuklara daha iyi bir eğitim verilmelidir (Ö17).

Eğitimde imkân ve firsat eşitliğini săglamak amacıyla parasız yatılılık, burs, kredi ve başka yollarla gerekli yardımlar yapılmaktadır. Buna katılıyorum (Ö48).

Öğrencilere daha fazla kaynak ve teknolojik imkânlardan yararlanma şansı verilmelidir (

Tablo 18: 16-ilk-orta-lisede ücretsiz ders kitabı dağıtımı eğitimde imkân ve fırsat eşitliğini olumlu etkilemektedir.

\begin{tabular}{|c|c|c|}
\hline Görüş & Frekans & Yüzde \\
\hline Kesinlikle Katılıyorum & 36 & 59 \\
\hline Katılıyorum & 20 & 32.8 \\
\hline Kısmen Katılıyorum & 3 & 4.9 \\
\hline Katılmıyorum & 2 & 3.3 \\
\hline Kesinlikle Katılmıyorum & - & - \\
\hline Toplam & 61 & 100 \\
\hline
\end{tabular}

Tablo 18'e göre; katılımcılarım 36'sı (\%59) bu soruya kesinlikle katılıyorum, 20'si (\%32.8) katılıyorum, 3’ü (\%4.9) kısmen katılıyorum görüşünü belirtmişlerdir. 2 (\%3.3) katılımcı katılmıyorum görüşündedir. Buna göre katılımcıların yaklaşık tamamına yakını ilk-orta-lisede ücretsiz ders kitabı dağıtımı eğitimde imkân ve fırsat eşitliğini olumlu etkilediği görüşündedir. Katılımcıların doğrudan örnek cümleleri şu şekildedir:

Hele ki devletin ücretsiz dă̆ıttı̆̆ı ders kitapları kullandırmayıp kendi kafalarına göre öğrencilere kitap aldırıp dersi oradan işleyen ögretmenler... Tabi ki de maddi durumu kötü ögrenciler o kitabı ya aylar sonra alabilir ya da hiç alamaz ve arkadaşları kitaptan işlerken o defterine soruları yazmakla uğraşır. Ĕ̆er öğrencilerimizi çocuklarımız gibi görürsek onlarla çocuklarımızın sorunlarıyla uğraşır gibi uğraşırız (Ö19).

Tablo 19: 17-Taşımalı eğitim eğitimde imkân ve fırsat eşitliğini olumlu etkilemektedir.

\begin{tabular}{lcc}
\hline Görüş & Frekans & Yüzde \\
\hline Kesinlikle Katılıyorum & 11 & 18
\end{tabular}




\begin{tabular}{|c|c|c|}
\hline Katılıyorum & 37 & 60.7 \\
\hline Kısmen Katılıyorum & 11 & 18 \\
\hline Katılmıyorum & 2 & 3.3 \\
\hline Kesinlikle Katılmıyorum & - & - \\
\hline Toplam & 61 & 100 \\
\hline
\end{tabular}

Tablo 19'a göre; katılımcılarım 11'i (\%18) bu soruya kesinlikle katılıyorum, 37'si (\%60.7) katılıyorum, 11'i (\%18) kısmen katılıyorum görüşünü belirtmişlerdir. 2 (\%3.3) katılımcı katılmıyorum görüşündedir. Buna göre katılımcıların yaklaşık beşte dördü taşımalı eğitimin eğitimde imkân ve firsat eşitliğini olumlu etkilediği görüşündedir. Yaklaşık beşte bir katılımcı ise bu görüşe katılmamaktadır. Katılımcıların doğrudan örnek cümleleri şu şekildedir:

Son dönemlerde yapılan projeleri başarılı buluyorum. Köy okullarına ve bu okullarda okuyan çocukların ailelerine ekstra özen verilmesi, maddi ve manevi destekte bulunulmasi gerektiğini düşünüyorum (Ö26).

Tablo 20: 18-'Haydi Kızlar Okula', 'Baba Beni Okula Gönder', 'Kardelenler projesi' gibi kampanyalar ile öğrenime devam edemeyen kız çocuklarına fırsat eşitliği sağlanmıştır.

\begin{tabular}{|c|c|c|}
\hline Görüş & Frekans & Yüzde \\
\hline Kesinlikle Katılıyorum & 23 & 37.7 \\
\hline Katılıyorum & 31 & 50.8 \\
\hline Kısmen Katılıyorum & 5 & 8.2 \\
\hline Katılmıyorum & 1 & 1.6 \\
\hline Kesinlikle Katılmıyorum & 1 & 1.6 \\
\hline Toplam & 61 & 100 \\
\hline
\end{tabular}

Tablo 20'ye göre; katılımc1larım 23’ü (\%37.7) bu soruya kesinlikle katılıyorum, 31'i (\%50.8) katılıyorum, 5’i (\%8.2) kısmen katılıyorum görüşünü belirtmişlerdir. 1 (\%1.6) katılımcı katılmıyorum, 1 (\%1.6) katılımcı ise kesinlikle katılmıyorum görüşündedir. Buna göre katılımcıların yaklaşık tamamına yakını 'Haydi Kızlar Okula', 'Baba Beni Okula Gönder', 'Kardelenler projesi' gibi kampanyalar ile öğrenime devam edemeyen kız çocuklarına firsat eşitliği sağlandığı görüşündedir. Katılımcıların doğrudan örnek cümleleri şu şekildedir: 
Şuan ülkemizde imkâna ve firsat eşitliği sağlama amaçlı çalışmalar devam ediyor. Bu çalışmaların büyük ölçüde faydasın gördüğümüzü de söyleyebilirim. Tabi bu coğrafi olarak bölgeden bölgeye göre farkllllklar göstermekte (Ö58).

Tablo 21: 19-Eğitim yoluyla alt ve orta tabaka ailelerinin çocukları dikey hareketlilik yaparak daha üst tabakalara geçebilmektedir.

\begin{tabular}{|c|c|c|}
\hline Görüş & Frekans & Yüzde \\
\hline Kesinlikle Katılıyorum & 17 & 27.9 \\
\hline Katılıyorum & 23 & 37.7 \\
\hline Kısmen Katılıyorum & 19 & 31.1 \\
\hline Katılmıyorum & 1 & 1.6 \\
\hline Kesinlikle Katılmıyorum & 1 & 1.6 \\
\hline Toplam & 61 & 100 \\
\hline
\end{tabular}

Tablo 21'a göre; katılımcılarım 17'si (\%27.9) bu soruya kesinlikle katılıyorum, 23'ü (\%37.7) katılıyorum, 19’u (\%31.1) kısmen katılıyorum görüşünü belirtmişlerdir. 1 (\%1.6) katılımc1 katılmıyorum, 1 (\%1.6) katılımcı kesinlikle katılmıyorum görüşündedir. Buna göre katılımcıların yaklaşı beşte dördü eğitim yoluyla alt ve orta tabaka ailelerinin çocukları dikey hareketlilik yaparak daha üst tabakalara geçebildiği görüşündedir. Yaklaşık beşte bir katılımcı ise bu görüşe katılmamaktadır. Katılımcıların doğrudan örnek cümleleri şu şekildedir:

Tüm bireylerin eğitim görme hakkına sahip olması ve imkân ve firsat eşitliğini olması gerektiğini düşünüyorum (Ö51).

Bir eğitimci olarak imkân ve firsat eşitliğinin çok önemli olduğunu düşünüyorum. Çünkü geleceğimizi garanti altına almak istiyorsak gençlerimizi iyi yetiştirmeliyiz (Ö25).

Tablo 22: 20-Salgın süreci tüm eğitim kademelerinde eğitimde imkân ve fırsat eşitliğini olumsuz etkilemiştir.

\begin{tabular}{lccc}
\hline Görüş & Frekans & Yüzde \\
\hline Kesinlikle Katılıyorum & & 36 & 59 \\
Katılıyorum & 16 & & 26.2 \\
Kısmen Katılıyorum & & 7 & 11.5 \\
Katılmıyorum & 2 & 3.3 \\
Kesinlikle Katılmıyorum & - & -
\end{tabular}


Tablo 22'ye göre; katılımcılarım 36's1 (\%59) bu soruya kesinlikle katıllyorum, 16's1 (\%26.2) katılıyorum, 7'si (\%11.5) kısmen katılıyorum görüşünü belirtmişlerdir. 2 (\%3.3) katılımc1 katılmıyorum görüşündedir. Buna göre katılımcıların yaklaşık tamamına yakını salgın sürecinin tüm eğitim kademelerinde eğitimde imkân ve firsat eşitliğini olumsuz etkilediği görüşündedir. Katılımcıların doğrudan örnek cümleleri şu şekildedir:

Okulumuzda imkân ve firsat eşitliğine dikkat edildiğini düşünmüyorum. Eşitsizlik durumlarında hocalarımızın vicdanlarına bırakiyor fakat vicdanları bizden yana olmayabiliyor. Özellikle uzaktan eğitimde imkânı olmayan öğrencilere kolaylı sağlandığını düşünmüyorum (Ö14).

Illk olarak uzaktan eğitimde her ögrrenci eşit imkân l sağlayamadl. Bu süreçte ders konusunda eksiklikleri olmuş olabilir. Ancak bunun dişında yüz yüze eğitimde çoğu öğrenci ekonomik durumlar dışında hemen hemen eşit imkânlardadır (28).

Mesela eğitime katılamayan derslere giremeyen öğrencilere tolerans sağlanabilir her insanın bulunduğu yerde İnternet olmayabilir ya da çekmeyebilir devamsılzlktan bu yüzden kalacak olanlar olabilir her insanın tek işi ders çalı̧̧mak olmayıp ailesini geçindirmeye çalışan bir yandan ders çalışan, hastaya bakan vb işler yapan insanlara biraz daha ayrıcalık taninabilir. Sirf devlette çalı̧̧mıyor diye bir sürü tarlası arabası olan insanların burs alıp ta devlette mevsimlik iş̧̧i olup 3 çocuğu da üniversiteye giden bir kişinin burs alamaması adaletli değil bu konuda daha iyi araştırma yapılabilir (Ö30).

Okul, ögretmen, materyal gibi unsurlar ülkemizdeki tüm ögrencilere ulaştırllmaya çalışıllyyor. Bu durum imkân ve firsat eşitliğine katkı sağlar. Ancak okul dışı öğrenme ortamları (tiyatro, müze, kütüphane, sanat merkezi, bilim merkezleri vb.) da eğitimin bir parçasıdır ve bu alanlarda da imkân ve firsat eşitliğini sağlama yönünde çalışmalar yapılmalıdır (Ö44).

\section{TARTIŞMA}

Eğitimde eşitlik, imkân ve firsat eşitliği konusu dünyanın birçok ülkesinde artan bir şekilde araştırılmaya ve çalışılmaya devam etmektedir (Burbules vd, 1982; Parry, 1996; Beblavy, Thum, \& Veselkova, 2011; Anderson, 2007; Kujovich, 1987, 72). Burada imkân ve firsat eşitliğinin 
yasalarda yer alması, bunun gerçekleştiği anlamına gelmemektedir (Lazenby, 2016, 65). Bu çalışmalarda; aradan geçen onca yıla rağmen eğitimde fırsat eşitliğine istenilen düzeyde ulaşılamadığı ortaya çıkmaktadır. Yeni politikalar ve uygulamalar ile birtakım düzelmeler yapılmaya çalışılmış olmakla birlikte, bu konuda ciddi çalışmalara ihtiyaç duyulmaktadır.

Türk eğitim sisteminin en önemli problemlerinden biri imkân ve firsat eşitliğidir. 1-3 Aralık 2021 tarihinde toplanan 20. Milli Eğitim Şurası'nın başlı̆̆ı "Eğitimde Fırsat Eşitliği” olarak belirlenmiştir. 20. Milli Eğitim Şurası'nda kurulan "Temel Eğitimde Fırsat Eşitliği", "Mesleki Eğitimin İyileştirilmesi" ve "Öğretmenlerin Mesleki Gelişimi" özel ihtisas komisyonlarında benimsenen maddeler ve ilave maddelerle toplam 128 maddelik tavsiye kararları kabul edilmiştir. Şurada alınan 128 tavsiye kararının 119'u oy birliği, 9'u da oy çokluğuyla kabul edilmiştir (Akşam, 2021).

İmkân ve fırsat eşitliğinin en önemli uygulamalarından biri 2019 yılının Aralık ayında ortaya çıkan ve tüm dünyaya yayılan salgın hastalık döneminde görülmüştür. Günümüze kadar devam eden süreçte eğitim yüz yüze, uzaktan ve karma şekilde devam etmiştir. Şura' da bu konu şu şekilde ele alınmıştır: "Yüz yüze eğitime ve öğretime engel olacak hallerde, salgın hastalıklar, afet durumu, süreğen hastalık durumu ve benzeri eğitim öğretim sürecinin kesintisiz devam etmesi için uzaktan eğitim, dijital altyapı ve alternatif erişim imkânlarını artıracak tedbirler alınmalıdır (35. Madde)” (Akşam, 2021).

Salgın hastalık sürecinde öğretmenlerin yeni koşullara özellikle uzaktan eğitime uyum sağlamasında sorunlar yaşanmıştır. Bu konuda Şura'da şu madde kabul edilmiştir: “Öğretmenlerin mesleki gelişim programları güncel ihtiyaçlar temelinde belirlenmelidir. Bu kapsamda, teknoloji, uzaktan eğitim harmanlanmış eğitim, çevrim içi psikolojik danışmanlık, özel eğitim ve kaynaştırma eğitimi, yabancı dil, bağımlılıkla mücadele, temel sağlık bilgisi, afet yönetimi ve acil durum eğitimleri verilmelidir. Hizmet içi eğitimler yüz yüze, uzaktan ve harmanlanmış olarak çeşitlendirilmelidir (99. Madde)" (Akşam, 2021).

20. Milli Eğitim Şurası'nın kapanış töreninde konuşan Milli Eğitim Bakanı Mahmut Özer, "Bu Şura kararlarının Milli Eğitim Bakanlığı olarak takipçisi olacağız. 3 ay içerisinde bir rapor yayımlayarak, alınan kararların uygulanma haritasını hem Şura üyeleri hem de tüm kamuoyu ile paylaşacă̆ız" şeklinde açıklama yapmıştır (Sondakika, 2021). 
Milli Eğitim Şura kararlarının bir özelliği tavsiye niteliğinde olmasıdır. Geçmişten günümüze şuralarda fırsat eşitliği kapsamında alınan kararlar vardır. Yakın geçmişten günümüze şura kararlarının gerçekleşmesinin incelendiği bir çalışmada; şura kararlarından gerçekleşenler olduğu gibi, kâğıt üzerinde kalanlar da bulunmaktadır (Sunar, 2021, 11 vd). Çeşitli paydaşlardan oluşan Şura'nın kararlarının uygulamada yer alması Türk eğitim sistemine olumlu katkılar sağlayacaktır.

\section{SONUÇ VE ÖNERILER}

Öğrencilerin yaklaşık beşte dördünün görüşüne göre Türk eğitim sisteminde imkân ve firsat eşitliği gerçekleşmektedir. Öğrencilerin görüşlerine göre ekonomik, coğrafi, toplumsal ve siyasal faktörler imkân ve firsat eşitliğinin gerçekleşmesini etkilemektedir.

Öğrencilerin büyük çoğunluğuna göre eğitimde imkân ve firsat eşitliğini ekonomik faktörler etkilemekte, ailenin gelir düzeyi eğitimde imkân ve firsat eşitliğini olumlu ya da olumsuz etkilemekte, köylerde çocukların tarlada, bağda, hayvancılık işlerinde çalışması eğitimde imkân ve firsat eşitliğini etkilemektedir. Ortaokullara aktarılan kaynakların dağıtımı ve kullanımı konusunun araştırıldığı bir çalışmada okullar arasında eşitsizlik saptanmıştır (Petek ve Önder, 2015, 1098). Üniversite öğrencileri üzerine yapılan bir araştırmada, ekonomik düzeyi düşük olan öğrencilerin özel üniversitelere gidemediği ve devlet yüksekokullarını tercih ettiği bulunmuştur (Kandemir ve Kaya, 2010, 557). Başka bir çalışmada, imkân ve firsat eşitliğinin gerçekleşmesinde devletin ailelerin ekonomik ve sosyal yapılarına yönelik desteğinin olması zorunlu olduğu tespit edilmiştir (Tabak, 2019, 370). Giresun özelinde yapılan araştırma eğitimde aileler arasında sosyoekonomik yönden eşitsizlik belirlenmiştir (Yaşar, 2014).

Öğrencilerin büyük çoğunluğuna göre eğitimde imkân ve firsat eşitliğini coğrafi faktörler etkilemektedir. İlköğretim ikinci kademede yapılan bir araştırmada coğrafi faktörlerin ortaya çıkardığg eşitsizlikler ortaya konulmuş ve çözüm önerileri sunulmuştur (Buluç, 1997, 11). Meslek liselerine yönelik bir araştırmada farklı coğrafi yerlere öğrenim amaçlı gitmek zorunda kalan meslek lisesi 11. Sınıf öğrencilerinin imkân ve fırsat eşitsizliğine uğradığı sonucu bulunmuştur (Ergün, 2019, 1). Üniversite öğrencileri üzerine yapılan bir çalışmada pozitif ayrımcılık uygulamaların eşitsizlikleri giderdiği sonucuna ulaşılmıştır (İnan ve Demir, 2018, 337). 
Üniversiteye girişte bölgelerin incelendiği bir çalışmada eşitsizlik saptanmış ve devletin bu konuda yeni eğitim politikaları oluşturması önerilmiştir (Kartal, 2009, 45).

Öğrencilerin büyük çoğunluğuna göre, ailenin eğitim düzeyi yüksek olduğunda çocukların eğitimde imkân ve firsat eşitliğinden daha çok yararlandığı görüşündedir. Öğrencilerin yaklaşık dörtte üçüne göre kadın-erkek ayrımının kız çocuklarının eğitimini engellemektedir. Öğrencilerin yaklaşık beşte üçü resmi dil dışında kalan yerel dillerin eğitimde imkân ve firsat eşitliğini olumsuz etkileyebilmektedir görüşündedir.

Öğrencilerin büyük çoğunluğuna göre eğitim politikaları eğitimde imkân ve firsat eşitliğini etkilemektedir. Öğrencilerin yaklaşık tamamına yakını göre ilk-orta-lisede ücretsiz ders kitabı dağıtımı eğitimde imkân ve fırsat eşitliğini olumlu etkilemektedir. Öğrencilerin yaklaşık beşte dördüne göre taşımalı eğitimin eğitimde imkân ve fursat eşitliğini olumlu etkilemektedir. Katılımcıların yaklaşık tamamına yakını 'Haydi Kızlar Okula', 'Baba Beni Okula Gönder', 'Kardelenler projesi' gibi kampanyalar ile öğrenime devam edemeyen kız çocuklarına fırsat eşitliği sağlandığg görüşündedir. Katılımcıların büyük çoğunluğuna göre okullarda yeterli sayı ve nitelikte öğretmen olmaması eğitimde imkân ve firsat eşitliğini etkilemektedir. Öğrencilerin yaklaşık beşte dördüne göre eğitim yoluyla alt ve orta tabaka ailelerinin çocukları dikey hareketlilik yaparak daha üst tabakalara geçebilmektedir. Ortaokullarda görev yapan öğretmenler üzerine yapılan bir çalışmada köy ve şehir okulları arasında eşitsizlik saptanmıştır. Köy okulları ve dezavantajlı bölgelerde öğretmenler daha fazla tayin yapmakta, daha fazla ücretli öğretmenler çalışmakta ve deneyimli öğretmenler merkezi okullarda görev almaktadır (Petek ve Önder, 2015, 1098). Taşımalı eğitim üzerine yapılan bir çalışmada, bu uygulamanın öğrencilerin imkân ve firsat eşitliğine kavuşması açısından olumlu, öğrenci başarısı üzerine olumsuz etkisinin olduğu saptanmıştır (Cesur, 2021, 125). Başka bir çalışmada, eğitimde yapılan uluslararası sınavların sonuçlarına göre eğitimde özelleşme politikaların mevcut eşitsizliği daha da derinleştiği sonucuna ulaşı1mıştır (Güner vd, 2014, 33). 'Haydi Kızlar Okula' kampanyasının ilköğretimde cinsiyet eşitliğine olumlu yansıdığ 1 ve bu tür projelerin artarak devam etmesi gereği saptanmıştır (Gümüş ve Gümüş, 2013, 17). Günümüzde, sosyal hareketlilikte en önemli araç eğitimdir (Arslanoğlu, 2017, 165; Doğan, 2007, 321 va).

Öğrencilerin büyük çoğunluğuna göre özel eğitime ve korunmaya muhtaç çocukları yetiştirmek için özel tedbirler alınmaktadır. Katılımcıların yaklaşık beşte dördü eğitimde eşitlik ilkesine 
uyulduğu görüşündedir. Katılımcıların yaklaşık yarısından biraz fazlasına göre eğitimde yöneltme ilkesine uyulmaktadır. Yaklaşık yarıdan biraz az katılımcı ise bu görüşe katılmamaktadır. Öğrencilerin yaklaşık beşte dördü eğitim hakkı ilkesine uyulduğu görüşündedir. Katılımcıların yaklaşık beşte dördüne göre eğitimde fırsat ve imkân eşitliği ilkesine uyulmaktadır. Öğrencilerin yaklaşık beşte dördü eğitimde imkân ve firsat eşitliği araçlarına uyulduğu görüşündedir. Üstün yetenekli öğrencilerin eğitimde imkân ve firsat eşitliğinden yararlanmasına yönelik yapılan bir çalışmada, çok yönlü çalışma gerektiği sonucuna ulaşılmıştır (Gürültü ve Alcı, 2020, 2413). Başka bir çalışmada, üstün yetenekli öğrencilerinin eğitiminde rehberlik hizmetleri çok önemli bir faktör olduğu bulunmuştur (Hotaman ve Yüksel Şahin, 2009). Okul yöneticilerine yönelik yapılan bir araştırmada, kapsayıcı eğitim uygulamalarının eğitimde imkân ve firsat eşitliğini olumlu etkileyeceği ancak bu konuda okulların donanım ve personel olarak yetersiz olduğu sonuçlarına ulaşılmıştır (Asar, 2020).

Öğrencilerin yaklaşık tamamına yakını göre salgın sürecinin tüm eğitim kademelerinde eğitimde imkân ve firsat eşitliğini olumsuz etkilenmiştir. Bu konuda yapılan bir araştırma öğrencilerin görüşünü desteklemektedir (Karaağaçlı, 2021).

20. Milli Eğitim Şurası'nda alınan 128 maddelik tavsiye kararların kesinlikle uygulanması önerilebilir. Türk eğitim sisteminde eğitimde imkân ve firsat eşitliğine yönelik, nicel, nitel ve karma çalışmalar yapılabilir.

\section{KAYNAKLAR}

Akşam. (2021). 20. Milli Eğitim Şurası'nda kabul edildi... işte 128 maddelik tavsiye kararları.

https://www.aksam.com.tr/egitim/20-milli-egitim-surasinda-kabul-edildi-iste-128-maddelik-tavsiyekararlari/haber-1224343, Erişim:19.12.2021.

Akyüz, E. (2020). Çocuk hukuku. Ankara: PegemA Yayıncılık.

Anderson, E. (2007). Fair opportunity in education: A democratic equality perspective. Ethics, 117(4), 595-622. 
Arslanoğlu, i. (2017). Sosyolojiye giriş. Ankara: Akçağ Yayınları.

Arslan, C.., \& Kayançiçek, E. (2010). T.C. anayasası. İstanbul: Hürriyet Yayınları.

Asar, M. (2020). Kapsayıcı öğrenme ortamlarına ilişkin yöneticilerin görüşleri (Denizli ili Pamukkale ilçe örneği). http://acikerisim.pau.edu.tr/xmlui/handle/11499/35046, Erişim:19.12.2021.

Beblavy, M., Thum, A. E., \& Veselkova, M. (2011). Education policy and welfare regimes in OECD countries: Social stratification and equal opportunity in education. CEPS working document, (357).

Buluç, B. (1997). Ilköğretim ikinci k a d e m e o k u ll a r d a eğitimde fırsat ve imkan eşitliği. Eğitim \} önelimi, Yıl 3, Sayı 1, Kı.ş 1997, ss. 11-21.

chromeextension://efaidnbmnnnibpcajpcglclefindmkaj/viewer.html?pdfurl=https\%3A\%2F\%2

Fdergipark.org.tr\%2Fen\%2Fdownload\%2Farticle-file\%2F108626\&chunk=true, Erişim: 19.12.2021.

Burbules, N. C., Lord, B. T., \& Sherman, A. L. (1982). Equity, equal opportunity, and education. Educational Evaluation and Policy Analysis, 4(2), 169-187.

Büyüköztürk, Ş. ve Diğerleri (2016). Bilimsel araştırma yöntemleri. Ankara: PegemA Yayıncılık.

Celkan, H. Y. (1991). Eğitim sosyolojisi. Erzurum: Atatürk Üniversitesi Yayınları.

Cesur, A. (2021). Fırsat eşitliği temelinde taşımalı eğitim uygulaması: Kızılırmak ilçesi örneği. Bildiriler Kitabı-IV, 125.

Çelikkaya, H. (1998). Fonksiyonel eğitim sosyolojisi. İstanbul: Alfa Yayınları.

Doğan, i. (2007). Sosyoloji, kavramlar ve sorunlar. Ankara: PegemA Yayınları.

Ergün, (2019). Eğitimde fırsat ve imkân eşitliğine farklı bir bakış. Celal Bayar Üniversitesi Sosyal Bilimler Dergisi. 17/2019, 3, 1-17.

Gümüş, S. ve Gümüş, E. (2013). Türkiye' de "haydi kızlar okula" kampanyası yardımı ile ilköğretimde cinsiyet eşitliğinin sağlanması. Eğitim ve Bilim, [S.I.], v. 38, n. 167, feb. 2013. ISSN 1300-1337.

Erişim

Adresi: http://egitimvebilim.ted.org.tr/index.php/EB/article/view/866/464>. Erişim Tarihi: 19 Dec. 2021.

Güner, H., Çelebi, N., Taş̧̧ı Kaya, G., \& Korumaz, M. (2014). Neoliberal eğitim politikaları ve eğitimde fırsat eşitliği bağlamında uluslararası sınavların (PISA, TIMSS ve PIRLS) analizi. Journal of History Culture and Art Research, 3(3), 33-75. Retrieved from http://193.140.9.50/index.php/ilk/article/view/329 
Gürbüztürk, O. (2019). Eğitimde eşitsizlikler: eğitimde fırsat ve imkân eşitliği. Eğitim Sosyolojisi (Editörler: Erdoğan Köse ve Salih Zeki Genç). Ankara: PegemA Yayınları. 209-222.

Gürültü, E. \& Alcı, B. (2020). Üstün yetenekli öğrencilerin eğitiminde fırsat eşitliği bağlamında öğrenci ve veli görüşleri. OPUS International Journal of Society Researches, 15 (24) , 24132442 . DOI: 10.26466/opus.621789.

Hotaman, D., \& Yüksel Şahin, F. (2009). Üstün yetenekli öğrencilerin eğitiminde fırsat eşitliği ile kişisel, eğitsel ve mesleki rehberlik yardımı. In The 5th International Balkan Education and Science Congress' de sunulmuş sözlü bildiri, Trakya Üniversitesi, Edirne.

Kandemir, O. \& Kaya, F. (2010). Gelir dağılımının yüksek öğrenimde fırsat eşitliğine etkisi: Türkiye'de özel üniversite gerçeği. Kastamonu Eğitim Dergisi, 18 (2) , 557-566. Retrieved from https://dergipark.org.tr/en/pub/kefdergi/issue/49063/626005

Karaağaçlı, M. (2021). Salgında ulusal eğitimin fırsat ve imkân eşitsizliğinde tiranlaştırılıp tanrılaştırılan bilişim. Eleştirel Pedagoji, 2021, 68, sny.

Karasar, N. (2014). Bilimsel Araştırma Yöntemi. Ankara: Nobel Yayıncılık.

Kartal, S. (2009). Üniversiteye girişte bölgeler arası fırsat eşitsizliği. Verimlilik Dergisi, (2) , 45-60. Retrieved from https://dergipark.org.tr/en/pub/verimlilik/issue/21747/233826.

Köse, E. \& Dağyar, M. (2019). Sosyolojinin temel kavramları ve sosyoloji bilimi. Eğitim Sosyolojisi (Editörler: Erdoğan Köse ve Salih Zeki Genç). Ankara: PegemA Yayınları.1-24.

Kujovich, G. (1987). Equal opportunity in higher education and the Black public college: The era of separate but equal. Minn. L. Rev., 72, 29.

Lazenby, H. (2016). What is equality of opportunity in education?. Theory and Research in Education, 14(1), 65-76.

İnan, M. \& Demir, M. (2018). Eğitimde fırsat eşitliği ve kamu politikaları: Türkiye üzerine bir değerlendirme. Ankara Hacı Bayram Veli Üniversitesi İktisadi ve İdari Bilimler Fakültesi Dergisi,20(2),337-359, Retrieved,from https://dergipark.org.tr/en/pub/ahbvuibfd/issue/39904/473769, Erişim:10.12.2021

Özkan, H. H. (2019). Sosyal Kurumlar ve Eğitim. Eğitim Sosyolojisi (Editörler: Erdoğan Köse ve Salih Zeki Genç). Ankara: PegemA Yayınları. 139-188.

Parry, T. R. (1996). Will pursuit of higher quality sacrifice equal opportunity in education? An analysis of the education voucher system in Santiago. Social Science Quarterly, 821-841.

Petek, H., Önder, E. (2015). Ortaokulların fırsat ve imkan eşitliği açısından değerlendirilmesi (Burdur il örneği). International Journal of Social Sciences and Education Research, 1 (3), 10981114. 
Sondakika. (2021). Milli Eğitim Bakanı Özer: "Şura kararlarının takipçisi olacağız"

https://www.sondakika.com/haber/haber-20-milli-egitim-surasi-nda-128-maddede-tavsiye-14572970/, Erişim: 19.12.2021.

Sunar, S. (2021). 20. Millî eğitim şûrası konularına ilişkin görüş ve öneriler. Ankara: TED Yayınları. https://tedmem.org/yayin/20-milli-egitim-surasi-konularina-iliskin-gorus-oneriler, Erişim: 10.10.2021.

Tabak, H. (2019). Türk Eğitim Sisteminde Eğitimde Fırsat Eşitliğine Kuramsal Bakış: Roller ve sorumluluklar. Türk Eğitim Bilimleri Dergisi, 17 (2) , 370-393 . Retrieved from https://dergipark.org.tr/en/pub/tebd/issue/50950/632475.

Tezcan, M. (2018). Eğitim sosyolojisi. Ankara: Anı Yayıncılık.

Yaşar, M. M. (2014). Sosyoekonomik açıdan eğitimde fırsat eşitliği: Giresun örneği (Master's thesis, Sosyal Bilimler Enstitüsü).

Yıldırım, A. \& Şimşek, H. (2011). Sosyal bilimlerde nitel araştırma yöntemleri. Ankara:

Yüksek Öğretim Kurumu (YÖK). (2021). Yeni öğretmen yetiştirme lisans programları.

https://www.yok.gov.tr/kurumsal/idari-birimler/egitim-ogretim-dairesi/yeni-ogretmen-yetistirme-

lisans-programlari, Erişim: 19. 06.2021. 